\title{
Bacteriochlorophylls modified at position C-3: long-range intramolecular interaction with position $\mathrm{C}-13^{2}$
}

\author{
A. Struck ${ }^{\text {a }}$, E. Cmiel ${ }^{\text {b }}$, I. Katheder ${ }^{\text {a }}$, W. Schäfer ${ }^{c}$ and H. Scheer ${ }^{*}$ \\ "Botanisches Institut der Unicersität, München (Germany), "In.titut für Physikalische und Theoretische Cheme. Tethnisch" \\ Unitersität München, Garching (Germany) and 'Max Planck Institut für Biochemie, Martinsried (Germany')
}

(Received 17 Januan 1992)

Key words: Vinyl substituent: Hydroxyethvl substituent: Allomerization; Pyro-bacteriochlorophyll: Hydroxy substituent: Water elimination; Enolization; Photosynthesis

[3-Vinyl]-bacteriochlorophyll $a$ and related pigments modified at C-3 and/or C-132 have been synthesized from bacteriochlorophyll $a$. The reactivity at C-3 is strongly influenced by the $C-13^{2}$ substituent, and vice versa. Spectroscopical data and comparison among derivatives modified at the isocyclic ring indicate that this interaction is related to formation of an intermediate enol(ate) structure. The possible role of enol(ate) formation in (bacterio)chlorophylls in nature is discussed.

\section{Introduction}

The chemistry of plant chlorophylls (Chl $a, b)$ is a well-studied part of porphyrin chemistry. A large amount of data has been accumulated on the chemical reactivity of side-groups and their physical and spectroscopic properties [1-3]. Much of that work is motivated by the impor ince of these chlorophylls in oxygenic photosynthesis. While most of these data originate from in vitro work in organic or micellar solution. much less is known on the structural and functional details in their native protein environment. In the case of bacteriochlorophylls, among which $\mathrm{BChl} a$ and $b$ are most prominent, the situation is reversed. Due to the possibility to isolate bacterial light-harvesting complexes [4] and purple bacterial reaction centers [5] for more than 15 years, and to crystallize some of them, high precision structural data in their native protein environment are available [6-10]. However, their chemistry is relatively seldom investigated. In connection with the recently introduced methods for exchanging modified (bacterio)chlorophylls and -pheophytins into bacterial reaction centers [11-14] (no detailed reports have been given there on the pigment synthe-

Correspondence: H. Scheer. Botanisches Institut, Universität München, Menzingerstr. 67, D-8000 München 19, Germany.

Abbreviations: Chl, chlorophyll; Phe. pheophytin: BChl, bacteriochlorophyll; BPhe, bacteriopheophytin. sis) and antennas [15-17], we have started to investigate the reactivity of side-groups in $\mathrm{BChl} a$.

To understand the structure-function relationships of bacteriochlorophylls (and chlorophylls) in more detail, it is important to obtain structural links between the different naturally occurring (bacterio)chlorophyll structures. One such link is [3-acetyl]-chlorophyll a [18], bearing the 3-acetyl group characteristic of $\mathrm{BChl}$ $a$ and $b$, and the macrocycle characteristic of the green plant $\mathrm{Chl} a$ and $b$. The complementary link is [3vinyl]-Bchl $a$, which differs vice versa from $\mathrm{Chl} a$ by the macrocycle, and from BChl $a$ by the presence of a $C-3$ vinyl instead of an acetyl group. Here, we wish to report a procedure to synthesize [3-vinyl]-BChl $a$ and some related pigments, and discuss some physical properties of these pigments in vitro. Attention is given to a pronounced, and hitherto unreported, long-range interaction between substituents at the positions 3 and $13^{2}$, which was observed during these studies. The reactivity at $\mathrm{C}-3$ is strongly influenced by the nature of the $\mathrm{C}-13^{2}$ substituent, and vice versa. The data suggest, that this 'connection' is related to frrmation of enol(ate) structures at the isocyclic ring. There has been considerable interest before in the enolisation and the epimerisation at $\mathrm{C}-13^{2}$, and their possible involvement in photosynthesis [19-23]. The results are discussed in this context.

\section{Material and Methods}

\section{General conditions}

All chemicals and solvents used were reagent grade. 


\section{Pigments}

The isolation of $\mathrm{BChl} a(1)$ and the syntheses and spectral ctaracterizations of all derivatives are given in the Appendix.

\section{Spectra}

Absorption spectra were recorded on a Lambda 2 photometer (Perkin Elmer). 'H-NMR spectra are recorded on an AX $360 \mathrm{MHz}$ machine (Bruker model) in pyridine- $d_{5}$, if not stated otherwisc. FAB mass spectra were obtained with the model $\mathrm{CH} 7 \mathrm{a} / \mathrm{SS} 100$ mass spectrometer (Varian MAT, Bremen). Extinction coefficients were determined by dissolving the pigments in ether to $A_{\text {NIR }}$ around 0.8 . A precisc absorption spectrum was recorded. The sample was then dried with a stream of nitrogen. and the $\mathrm{Mg}$-contents determined by atomic-absorption spectroscopy. The reported values and error limits are avarages from three to six determinations.

\section{Results and Discussion}

\section{Structures}

Ultraviolet-Vis-NIR absorption, ${ }^{i} \mathrm{H}-\mathrm{NMR}$ and mass spectra of all products are consistent with the given structures. The 3-acetyl group was converted to the vinyl group by $\mathrm{NaBH}_{4}$ reduction to yield [ $3 \alpha$-hydroxyethyl]-BChl $a$, followed by dehydration in refluxing toluene. The 3- $\alpha$-hydroxyethyl-derivative (4) has the absorption maxima and ${ }^{1} \mathrm{H}-\mathrm{NMR}$ shifts as described in Ref. [26]. The cpimer mixture at $C-3^{1}$ gives rise to the splitting of some signals, as in the $\mathrm{BChl} c, d, e$ series [30,31]. Reduction of the $13^{1}-\mathrm{C}=\mathrm{O}$ group, which occurs readily in chlorophylls $[32,33]$, has (quite surprisingly)

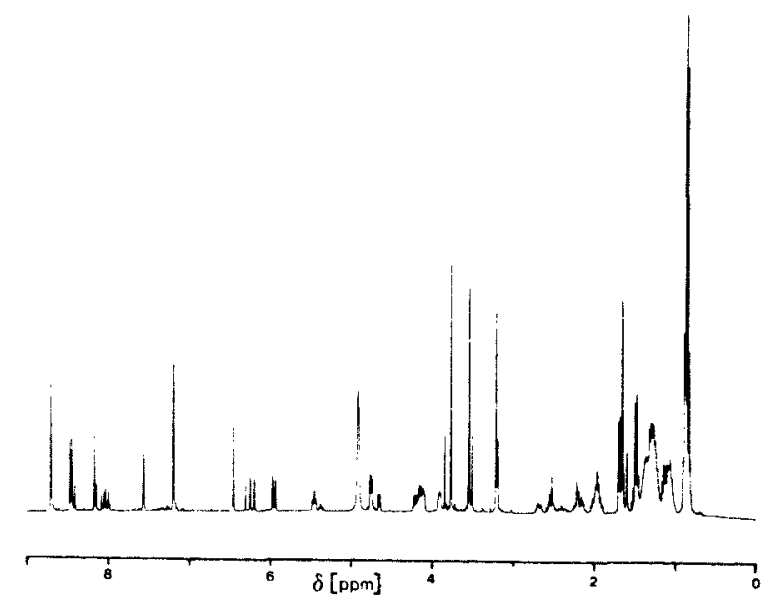

Fig. 1. 'H NMR spectrum of [3-vinyl]-BChl a (7) $\left(13^{2}\right.$-epimer mixture) in pyridine-d. Solvent signals at 7.2.7.56 and $8.69 \mathrm{ppm}$ (pyridine) and at $4.88 \mathrm{ppm}$ (water).

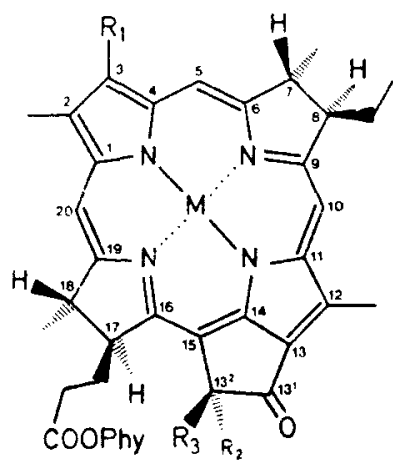

\begin{tabular}{|c|c|c|c|c|}
\hline & Rl & $\mathbf{R} 2$ & R3 & $\mathbf{M}$ \\
\hline 1 & $\mathrm{COCH}_{3}$ & $\mathrm{COOCH}_{3}$ & $\mathrm{H}$ & $\mathrm{Mg}$ \\
\hline $1^{\prime}$ & $\mathrm{COCH}_{3}$ & $\mathrm{H}$ & $\mathrm{COOCH}_{3}$ & $\mathrm{Mg}$ \\
\hline 2 & $\mathrm{COCH}_{3}$ & $\mathrm{H}$ & $\mathrm{H}$ & $\mathbf{M g}$ \\
\hline 3 & $\mathrm{COCH}_{3}$ & \multicolumn{2}{|c|}{$\mathrm{OH} / \mathrm{COOCH}_{3} *$} & $\mathrm{Mg}$ \\
\hline 4 & $\mathrm{HCOHCH}_{3} *$ & \multicolumn{2}{|c|}{$\mathrm{COOCH}_{3} \quad \mathrm{H}$} & $\mathrm{Mg}$ \\
\hline 5 & $\mathrm{HCOHCH}_{3} *$ & $\mathrm{H}$ & $H$ & $\mathrm{Mg}$ \\
\hline 6 & $\mathrm{HCOHCH}_{3} *$ & \multicolumn{2}{|c|}{$\mathrm{OH} / \mathrm{COOCH}_{3} *$} & $\mathrm{Mg}$ \\
\hline 7 & $\mathrm{CHCH}_{2}$ & $\mathrm{COOCH}_{3}$ & $\mathbf{H}$ & $\mathrm{Mg}$ \\
\hline 8 & $\mathrm{CHCH}_{2}$ & $\mathbf{H}$ & $\mathrm{H}$ & $\mathrm{Mg}$ \\
\hline 9 & $\mathrm{CHCH}_{2}$ & \multicolumn{2}{|c|}{$\mathrm{OH} / \mathrm{COOCH}_{3} *$} & $\mathrm{Mg}$ \\
\hline 10) & $\mathrm{COCH}_{3}$ & $\mathrm{COOCH}_{3}$ & $\mathrm{H}$ & $\mathrm{H}_{2}$ \\
\hline 11 & $\mathrm{COCH}_{3}$ & $\mathrm{H}$ & $\mathbf{H}$ & $\mathrm{H}_{2}$ \\
\hline 12 & $\mathrm{COCH}_{3}$ & \multicolumn{2}{|l|}{$\mathrm{C} \cdot \mathrm{H} / \mathrm{COOCH}_{3}{ }^{*}$} & $\mathrm{H}_{2}$ \\
\hline 13 & $\mathrm{HCOHCH}_{3}$ * & $\mathrm{COOCH}_{3}$ & $\mathrm{H}$ & $\mathrm{H}_{2}$ \\
\hline 14 & $\mathrm{HCOHCH}_{3}$ * & $\mathrm{H}$ & H & $\mathrm{H}_{2}$ \\
\hline 15 & $\mathrm{HCOHCH}_{3}$ * & \multicolumn{2}{|l|}{$\mathrm{OH} / \mathrm{COOCH}_{3} *$} & $\mathrm{H}_{2}$ \\
\hline 16 & $\mathrm{CHCH} 2$ & $\mathrm{COOCH}_{3}$ & H & $\mathrm{H}_{2}$ \\
\hline 17 & $\mathrm{CHCH}_{2}$ & $\mathbf{H}$ & H & $\mathrm{H}_{2}$ \\
\hline 18 & $\mathrm{CHCH}_{2}$ & $\mathrm{OH} / \mathrm{COOCH}_{3}$ & & $\mathrm{H}_{2}$ \\
\hline \multicolumn{4}{|c|}{ Phy = phytyl $\left(\mathrm{C}_{2 n} \mathrm{H}_{3,}\right)$} & \\
\hline
\end{tabular}

* Epimeric mixture.

never been observed under these conditions, not even at greatly prolonged times.

The 'H-NMR spectrum of [3-vinyl]-BChl $a$ (7) in pyridin (Fig. 1) shows the typical $\mathrm{AB}$ pattern of a vinyl group at $\delta=8.12,6.20$ and $5.93 \mathrm{ppm}$, the high-field shift of all signals with respect to chlorophyll is due to the reduced ring-current of bacteriochlorins [34]. The splitting of the methin proton signals at $8.46 / 8.45$, $8.44 / 8.41$ and $8.16 / 8.14$ and the $13^{2} \mathrm{H}$-signal at $6.44 /$ $6.29 \mathrm{ppm}$ indicates a $13^{2}$ epimeric mixture of about $70 \% 13^{2} \mathrm{~S}-(7)$ and $30 \% 13^{2} \mathrm{R}-(7)$. All other expected proton signals are present. After pyrolysis of the mixture, the resulting (8) shows no split signals in the 'H-NMR-spectrum.

The best way to produce $13^{2}$-hydroxylated BChl's is prolonged standing in methanol under aerobic conditions. The desired oxygenation $\left(13^{2}-\mathrm{OH}\right)$ and the undesired methoxylation $\left(13^{2}-\mathrm{OCH}_{3}\right)$ at this position are competing processes which occur with different yields (see Ref. 25). To obtain $13^{2}$-hydroxylated BChl's the product mixiure was subsequently separated by chromatography on DEAE-cellulose column [27]. Although 


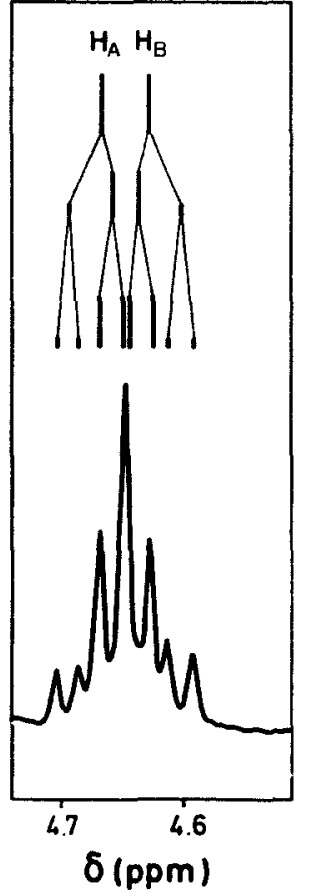

Fig. 2. ${ }^{1} \mathrm{H}$ NMR spectrum of $13^{2}$-hydroxy-BChl a (2) (13'-epimer mixture) in pyridine $-d_{5}$. The splitting of the $\mathrm{P}_{1}-\mathrm{CH}_{2}$ signal (centered at $4.65 \mathrm{ppm}$ ) is characteristic for $13^{2}$ hydroxylated bacteriochlerophylls in pyridine.

the resulting $13^{2}$ epimers can be separated on analytical TLC or HPLC, no attempts were made for a preparative separation. A remarkable feature in the NMR spectra of $13^{2}$-hydroxylated epimers concerns the signal at $4.63 \mathrm{ppm}$, which is assigned to the phytyl $\mathrm{P} 1-\mathrm{CH}_{2}$-group. It does not appear, as it usually does, as a doublet, but rather as a multiplet with seven resolved lines, which is the AB-part of an $\mathrm{ABM}$ system with $J_{\mathrm{AB}}=12.7 \mathrm{~Hz}$ and $J_{\mathrm{AM}}=J_{\mathrm{BM}}=7.2 \mathrm{~Hz}$ (Fig. 2).

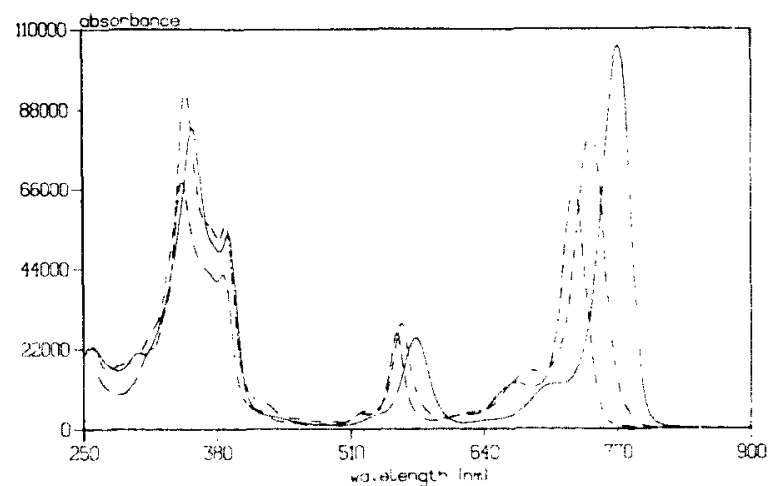

Fig. 3. Quantitative absorption spectra of bacteriochlorophylls. modified at position 3 in diethylether: BChl a (1), ( hydroxy-ethyl]-BChl a (4), (- - ) and [3-vinyl]-BChl $a$ (7). $(\cdot-\cdot \cdot)$

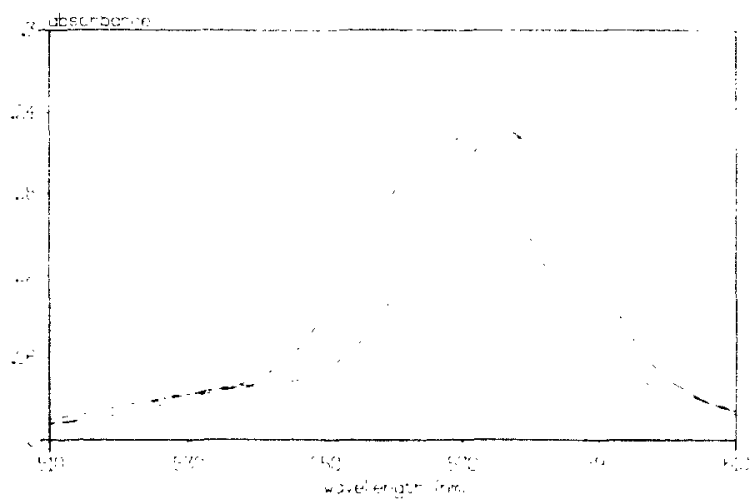

Fig. $+Q_{X}$-absorption hand of hacteriochlorophylls modified at position $13^{2}: \mathrm{BChl}$ a (1), (- $): 13^{2}$-demethoxycathonyl-BChl a (2) $(\ldots \ldots)$; and $13^{2}$ hydroxy-BChl $a(3),(\cdot \ldots \ldots)$.

This effect is typical for all $13^{2}$-hydroxylated pigments investigated. Such a pattern is probably the result of an increased anisochronicity, which results from interaction between the $13^{2} . \mathrm{OH}$ and the phytol residue in the (natural) $13^{2} S$-configuration.

\section{Absorption spectra and extinction coefficients}

Fig. 3 shows the quantitative absorption spectra in diethylether of BChl $a$ and the derivatives (4) and (7). modified only at position 3 . Compared with BChl $a(1)$. there is, for both modifications (as expected [35]), a characteristic short-wavelength shift of the $Q_{Y}$ and the $\mathrm{Q}_{\mathrm{X}}$ bands. For $3^{1}-\mathrm{OH}-\mathrm{BChl} a$, the $\mathrm{Q}_{\mathrm{Y}}$ band is shifted from $771 \mathrm{~nm}$ to $728 \mathrm{~nm}$. and the $Q_{X}$ band from $573 \mathrm{~nm}$ to $555 \mathrm{~nm}$. The $\mathrm{Q}_{Y}$ band of [3-vinyl]-BChl $a$ shifts from $771 \mathrm{~nm}$ to $745 \mathrm{~nm}$, and the $Q_{X}$ band from $573 \mathrm{~nm}$ to $560 \mathrm{~nm}$. It is worth noting the lowered extinction coefficient of the $Q_{Y}$ band for both modifications. It decreases from $\epsilon_{771}=105 \cdot 10^{3}$ for $\mathrm{BChl} a$ over $\epsilon_{7+5}=$ $83 \cdot 10^{3}$ for [3-vinyl]-BChl $a$ to $\epsilon_{72 x}=66 \cdot 10^{3} \mathrm{M}^{-1} \mathrm{~cm}^{-1}$ for [3- $\alpha$-hydroxyethyl]-BChl $a$ in diethylether.

Decarboxylation and hydroxylation at $\mathrm{C}-13^{2}$ only have a small effect on the absorption spectra, as in the chlorophyll series. There is, however, a small but distinct difference in the $\mathrm{Q}_{Y}$ region (Figs. 4 and 5). The $13^{2}$-demethoxycarbonyl $=$ pyro) compounds $(2)$ and $(8)$ shift always slightly to longer wavclengths, as compared to the respective (1) and (7), bearing a $13^{2}$. carbomethoxy substituent. The shift is most obvious in the short-wavelength flange. The $13^{2}$-hydroxylated products (3) and (9), in contrast, always shift to slightly shorter wavelengths, as compared to the $13^{2} \mathrm{H}$ compounds (1) and (7). This effect, irrespective of the modifications at C-3 (see Materials and Methods section for the [3- $\alpha$-hydroxyethyl]-bacteriochlorophylls (4). (5) and (6)), is also present in the $Q_{X}$ band of the curresponding metal-free compounds, e.g., the bacteriopheophytins (see Materials and Methods section 


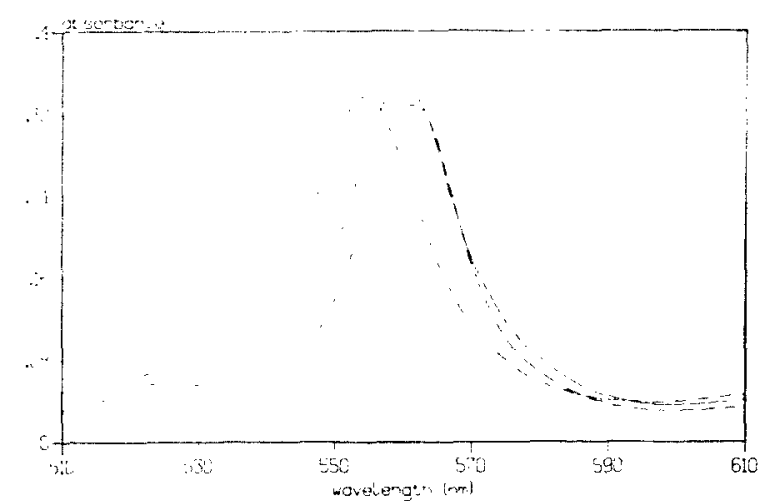

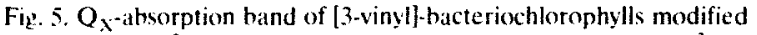
at position 1.32: [3-vinyl]-BChl a (7) (—). [3-vinyl]-13 $3^{2}$-demethoxycarbonyl-BChl a (8) (-_ _ $\rightarrow$ ) and $\left[3\right.$-vinyl] $13^{2}$-hydroxy$\mathrm{BChl} a(9),(\ldots))$.

and Ref. 29). $Q_{x}$ bund shifts are also induced by a different modification. e.g.. by the ligand number of the central $\mathrm{Mg}$ in chlorophylls and bacteriochlorophylls [36]. In the latter case. the change in ligation corresponds to a change in the macrocycle geometry (but see Ref. 37), which is less planar when the central $\mathrm{Mg}$ has only five ligands (e.g., one axial ligand). The underlying effect for the $13^{2}$-substituent shifts is also possibly steric changes of the macrocycle, because the $13^{2}$ substitution pattern can influence the 'puckering' of the macrocycle [38].

Water elimination and reciprocal interaction between positions $\mathrm{C}-3$ and $\mathrm{C}-13^{2}$

The elimination of water at the $C-3$ substituent of [3- $\alpha$-hydroxyethyl]-BChl $a$ (4) proceeds smoothly in refluxing toluene under anhydrous conditions to yield [3-vinyl]-BChl $a(7)$. It is remarkable that this elimination reaction at position 3 is strongly dependent on the $13^{2}$ substituent. The $3^{1}, 13^{2}$-dihydroxylated pigment (6) does not yield the respective [3-vinyl]-pigment (9). Rather it remains stable even after several hours of refluxing. The 'H-NMR spectra of $13^{2}$ hydroxylated $\mathrm{BChl}$ 's consistently showed that they are very hygroscopic, which could be a cause for the changed reactivity. This was ruled out, however, by extensive drying. Repeated evaporation of dry toluene from the pigments under a stream of nitrogen, before attempting the elimination, did not promote the dehydration at the $C-3$ substituent. Moreover a similar influence of the $13^{2}$-substituents was found with the $13^{2}$-demethoxycarbonyl (= pyro) $\mathrm{BChl} a(5)$. This pigment is not as hygroscopic as are $13^{2}$-hydroxy-BChl's, but again the elimination reaction was negative. Even after $6 \mathrm{~h}$ of refluxing in toluene. $(5)$ is stable and does not yield the expected (8). These experimental data confirm a dis- tinct influence of the $13^{2}$ substitution pattern on the reactivity of $\mathrm{C}_{-3^{\prime}}$. One way to rationalize the interaction over such a distance would be a bimolecular mechanism in which one pigment catalyses the reaction of the other, e.g., in a 'head-to-tail' aggregate [39-42]. To test this idea, the reaction was followed at lowered concentrations of pigments in toluene, and also in pyridin. which is known to prevent aggregations. In neither case was there a marked change in the water elimination kinetics. Taken together these experimental results exclude intermolecular interactions as the origin for the changed reactivities, and leave as alternative an intramolecular long-range interaction of the $\mathrm{C}-13^{2}$ on the $\mathrm{C}-3$ sites.

Interestingly, there is also evidence for the reverse influence of the $3^{1}$-substituent on reactions of the isocyclic ring. The hydroxylation rate of [3-vinyl]-BChl $a(7)$ at $\mathrm{C}-13^{2}$ in methanol is much lower than that of $\mathrm{BChl} a$ (1). Further results come from reactions in alkaline methanol $[43,44]$. Under conditions where (1) is converted to (Rhodo)bacteriochlorin- $e_{7}$-methylester, the isocyclic ring $V$ remains intact in (7) [29].

\section{Which role does keto-enol tautomerism play?}

A common aspect of the two compounds, (5) and (6) which do not eliminate water from the C-3 substituent, is that enolization at the isocyclic ring is greatly reduced (5) or even inhibited (6). (5) is no longer a $\beta$-ketoester, and enolization is no longer possible if the $13^{2}-\mathrm{H}$ of (1) or (4) is substituted by an OH-group as in (6). The readily enolizable $\beta$-ketoester is present in most (bacterio)chlorophylls, but the functional significance of this group is still unclear [19-23]. Enols can principally be formed by tautomeric shift of the $13^{2}-\mathrm{H}$ to either the $13^{l}$-carbonyl or the $13^{3}$-methoxycarbonyl oxygen, but all enolic structures reported so far are $13^{1}$-ene- $13^{1}$-ols $[19-23,45]$. Enolates can be formulated from all enols by proton dissociation. In most cases, the carbonyl tautomer is strongly favored and accounts, for example, for the absorption and vibrational spectra, and no significant amounts of chlorophyll enoltautomers are detected in organic solvents by the latter [46]. There is, for example, no distictive spectroscopic difference between the readily enolizable (1), the more difficult enolizable (2), and the non-enolizable (3), whereas the known enols differ considerably in their absorption from the keto-compounds. However, the ready $H$-exchange [47] and epimerisation of the chiral center $\mathrm{C}-13^{2}$ [48] are explained by this mechanism.

Vinylogous enolizations are possible as well, and, for example, account for the ${ }^{1} \mathrm{H} /{ }^{2} \mathrm{H}$-exchange at the $12-\mathrm{CH}_{3}$-group [49]. It is possible that the long-range effects described above are due to a more extensive vinylogous enolization. Enol(ates), which are substituted at the $\beta$-position by a suitable nucleophilic group, are prone to elimination forming $\alpha \beta$-unsaturated ke- 
tones. A number of enzymatic ([50-52] and for a review see Ref. 53) and non-enzymatic [54-57] reactions of this type have been studied in detail. Via the tetrapyrrolic $\pi$-system, the water elimination from (4) can then also be rationalized by a vinylogous mechanism.

It is worth noting the long distance over which the supposed enol(ate) formation can influence the reactivity of side-groups. There is another long-range intramolecular reaction known in chlorophylls, e.g., the electrophilic chlorination of Phe $a$ [58], which depends on the stereochemistry at $\mathrm{C}-13^{2}$. But in this case, probably steric rather than electronic factors are important.

It has been speculated for a long time that enolizations are important in vivo [19-23], because all bacteriochlorophylls and bacteriopheophytins in reaction centers carry the enolizable $\beta$-ketoester system. The long-range effect observed here is a further aspect to these speculations. It was significant in this context. that exchange of the enolizable (1) in bacterial reaction centers at the sites $B_{A . B}$ by the non-enolizable (3), did not interfere with charge separation, stability and VIS/NIR spectra [11,29]. The same is true for an exchange of (10) by (12) (or (18)) in the $\mathrm{H}_{B}$ binding site, while such an exchange was not readily possible at the $\mathrm{H}_{\mathrm{A}}$ binding site [29]. An enol formation of BPhe $a$ in $\mathrm{H}_{\mathrm{A}}$ which has been suggested from Raman spectroscopy [59], would explain the latter exchange results. However, ENDOR [60] and more recent Raman data [61] seem to exclude any enolic character of BPhe $a$ in $H_{A}$ in the ground or doublet states. In any event, in order to rationalize the possible role of enol(ate) formation of BPhe $a$ in $\mathrm{H}_{\mathrm{A}}$ it will be necessary to obtain more experimental and theoretical results about the influence of enol(ate)s on excited states and charge transfer states. One good tool for this will be the exchange experiments [11-14,29] in combination with IR/Raman spectroscopy (in particular with a stabilized BPhe $a^{--}$).

While the previous discussion was mainly concerned with static aspects, transient enol(ate) formation is another one, especially in photoenolization (for a review see Ref. 62). The photochemistry of aryl carbonyl compounds, such as acetophenone and benzophenone, is characterized by very efficient hydrogen abstraction from solvent or other hydrogen donors to give ketyl radicals, which then either couple to give pinacols or abstract hydrogen to give alcohols. However, the presence of an ortho-substituent carrying benzylic hydrogens almost completely quenches this intermolecular reaction and often renders the aryl carbonyl compound photochemically inert $[63,64]$. The mechanism of this quenching has been recognized as involving intramolecular hydrogen abstraction from the ortho-substituent by the carbonyl in a Norrish type II reaction to give a biradical, which can collapse to ground state dienols. This is preferable for anti-conformers. the syn-conformer converts directly from the excited $S^{\prime}$ state to ground state dienols. The unstable di-enols rapidly 're-ketonize' to give back the starting material, so that the initial photochemical excitation energy is ultimately dissipated as heat. Their ability to direct the de-excitation pathway has led to the use of these compounds to stabilize or destabilize polymers towards light.

For all known bacteriochlorophylls there is such a stabilizing 'ortho' substituent, e.g., the $12-\mathrm{CH}_{3}$ group (in syn-conformation). This could play the same stabilizing role in quenching excited states as an ortho methyl substituent in aryl carbonyl compounds. It is clear that, under normal photosynthetic conditions, this is an undesirable process. On the other hand, this quenching could become important in an environment or under conditions where the absorbed energy cannot be used in regular energy transfer (e.g., during biosynthesis or high light intensity conditions) or when they are functional in electron transfer. The functionality of the 'vinylogous' $12-\mathrm{CH}_{3}$ group depends on the environment; by interaction with this group, the reactivity of the excited state could be modulated. One such modulation may occur by the interaction of Glu-L141 and $13^{1} \mathrm{C}=\mathrm{O}$ of $\mathrm{BPhe}-\mathrm{H}_{\mathrm{A}}$ in reaction centers.

Irrespective of the mechanistic details the results show how the reactivity of bacteriochlorophylls could be influenced sensitively by substituents of the macrocycle, and probably also, by the environment of these substituents. This, then, may provide for switching or modulating the photophysical and photochemical properties of the pigment molecules in a reversible, environment-controlled, manner. It may be relevant to the different functions of bacteriochlorophylls in photosynthesis, and, in a dynamic manner, for the diode properties of reaction centers.

\section{Acknowledgements}

This work was supported by the Deutsche Forschungsgemeinschaft (SFB 143, Project A9). A.S. acknowledges a stipend from the Hanns-Seidel-Stiftung, München. The bacteria for isolating the BChl a were cultivated by the group of A. Ross in the phototrophic fermenter facilities at the Gesellschaft für Biotechnologische Forschung, Stöckheim. We thank P. Schraml (Gesellschaft für Strahlenforschung, Neuherbcrg) for atomic absorption analysis of $\mathrm{Mg}$.

\section{Appendix}

Pigment isolation, synthesis and characterization

$B C h l$ a (1). Isolated from Rhodobacter sphaeroides 2.4.1, as described before [12] as a $\mathrm{C}-13^{2}$ epimer mix- 
ture with $R / S$ around $90 / 10$. Spectra: absorption in ether, $\left.\lambda_{\text {thin }} / \mathrm{nm}\right]$ (relative intensitics): $S_{\mathrm{N}} * 357(0.78)$. $\left.S_{1}+91(0.51)\right), O_{Y} 573(0.23), 0,771 \mathrm{~nm}(1):\left(\epsilon_{-11}=\right.$ $\left(105 \pm 5 .(1) \cdot 10^{3} \cdot \mathrm{M}^{1} \cdot \mathrm{cm}{ }^{1}\right.$ in ether): ${ }^{1} \mathrm{H}-\mathrm{NMR}$ in pyridine- $d_{5}: \delta[\mathrm{ppm}]$ (proton): $9.52(5-\mathrm{H}): 8.64(10-\mathrm{H})$; 8.50 (20-H): $6.56\left(13^{2} \mathrm{R}-\mathrm{H}\right): 6.4^{2}\left(13^{2} \mathrm{~S}-\mathrm{H}\right): 3.45(2-$ $\left.\mathrm{CH}_{3}\right) ; 3.12\left(3^{2} \cdot\left(\mathrm{CH}_{1}\right): 1.70\left(7-\left(\mathrm{H}_{3}\right.\right.\right.$, d. $\left.J=7.2 \mathrm{~Hz}\right) ; 3.56$ $\left(12-\mathrm{CH}_{3}\right): 1.53\left(18-\mathrm{CH}_{3}\right.$, d. $\left.J=7.1 \mathrm{~Hz}\right) ; 3.78\left(13^{2}-\right.$ $\operatorname{COO}\left(\mathrm{H}_{3}\right) ; 4.75\left(\mathrm{P}_{1}\right): 5.45\left(\mathrm{P}_{2}\right): 1.65\left(\mathrm{P}_{3}\right)$.

1.32-Demethoxycarbomyl-BChl a (= Pro-BChl a) (2). Synthesized as described in Ref. 24. Spectra: absorption in ether $\lambda_{\max }[\mathrm{nm}]$ (relative intensities): $S_{\Lambda} 35$ (0.77), $S_{B} 390(0.43), O_{X} 576(0.22), Q_{Y} 771 \mathrm{~nm}(1) ;$ ${ }^{1} \mathrm{H}-\mathrm{NMR}$ in pyridine- $d_{5}: \delta[\mathrm{ppm}]$ (proton): $9.49(5-\mathrm{H})$; 8.72 (10-H); $8.61(20)-H): 5.29\left(13^{2}\right.$ R-H. d. $J=19.5 \mathrm{~Hz}$ ): $5.07\left(13^{2} \mathrm{~S}-\mathrm{H}\right.$. d. $\left.J=19.6 \mathrm{~Hz}\right): 3.52\left(2 \cdot \mathrm{CH}_{3}\right): 3.10\left(3^{2}-\right.$ $\left(\mathrm{CH}_{3}\right): 1.7\left(7-\mathrm{CH}_{3}\right) ; 3.68\left(12-\mathrm{CH}_{3}\right): 1.65\left(18-\mathrm{CH}_{3}\right): 4.75$ $\left(P_{1}\right): 5.47\left(P_{1}\right): 1.67\left(P_{i}\right)$.

$13^{2}$-Hydroxy-BC $/ 1$ a (3). Synthesized as described in Ref. 25. Spectrat: absorption in ether $\lambda_{\text {mix }}[\mathrm{nm}]$ (relative intensities): $S_{X} .357(0.78) . S_{B} 391$ (0.55). $Q_{X} 568$ (0.22), $Q_{Y} 771 \mathrm{~nm}(1)$ : 'H-NMR in pyridine- $d_{5}: \delta[\mathrm{ppm}]$ (proton): $9.65 \quad(5-\mathrm{H}): 8.71 \quad(10-\mathrm{H}): 8.60)(20-\mathrm{H}) ; 3.48$ $\left(2-\mathrm{CH}_{3}\right): 3.15\left(3^{2}-\mathrm{CH}_{3}\right): 1.74\left(7-\mathrm{CH}_{3}, \mathrm{~d}, J=7.1 \mathrm{~Hz}\right)$ : $3.56\left(12-\mathrm{CH}_{3}\right): 1.39(18-\mathrm{CH}$. d. $J=7.1 \mathrm{~Hz}) ; 3.57\left(13^{2}-\right.$ $\left.\mathrm{COOCH}_{3}\right) ; 9.66\left(13^{2}-\mathrm{OH}\right) ; 4.65\left(\mathrm{P}_{1}\right) ; 5.35\left(\mathrm{P}_{2}\right) ; 1.58$ $\left(P_{3}\right)$.

13-a-hydroxyethyl/-BChl a (4) (modified afier Ref. 26): $1(3-5 \mathrm{mg})$ was dissolved in $100 \mathrm{ml}$ ethanol and stirred under nitrogen at $4^{\circ} \mathrm{C}$. After $10 \mathrm{~min}$. $\mathrm{NaBH}_{4}(10$ $\mathrm{mg}$ ) was addeci and the reaction mixture kept stirred. The reaction is followed by Vis-NIR absorption spectroscopy (blue-shift of the $Q_{Y}$ band from $771 \mathrm{~nm}$ to $714 \mathrm{~nm}$ in the reaction mixture) and was generally complete after $30-60 \mathrm{~min}$. The mixture was then separated between diethyl ether and water. The ether phase, which contains the pigments, was washed repeatedly with water and then dried over $\mathrm{NaCl}$. The products were purified on a DEAE-cellulose column [27]: the four $3^{1} / 13^{2}$ diastereomers were not separated by this procedure. Spectra: absorption in ether $\lambda_{\max }[\mathrm{nm}]$ (relative intensities): $S_{A}, 346(1.03), S_{B} 387(0.64), Q_{X} 555$ (0.39), QY $728 \mathrm{~nm}(1) ; \epsilon_{72 \mathrm{x}}\left(66.1 \pm 3.2 \cdot 10 \mathrm{M}^{-1} \mathrm{~cm}^{-1}\right.$ in ether); ${ }^{1} \mathrm{H}-\mathrm{NMR}$ in pyridine-d $d_{5}$ : $\delta[\mathrm{ppm}]$ (proton): $8.88 * .8 .84^{*} .8 .83 *(5-\mathrm{H}) ; 8.37 *, 8.35 *(10-\mathrm{H})$; $8.02 * .8 .00 * 7.99 *(20-\mathrm{H}) ; 5.41\left(13^{2} \mathrm{R}-\mathrm{H}\right) ; 6.26 *$, $6.25 *(1.32 \mathrm{~S}-\mathrm{H}): 3.23 * 3.3 .18 *\left(2-\mathrm{CH}_{3}\right) ; 1.63\left(7-\mathrm{CH}_{3}\right)$; $3.51 * .3 .48 *\left(12-\mathrm{CH}_{3}\right) ; 1.46\left(18-\mathrm{CH}_{3}\right) ; 375 * .3 .83 *$. $3.74 *\left(13^{2}-\mathrm{COOCH}_{3}\right) ; 6.45\left(3^{\prime}-\mathrm{H}\right): 7.38\left(3^{\prime}-\mathrm{OH}\right):(*$ split signal due to presence of $3^{1} / 13^{2}$ diastereomers). [3-a-Hydroxyethyl]-132-demethoxycarbonyl-BChl a

\footnotetext{
$S_{S_{B}}=$ main components of the Soret hand system, $Q_{X, Y}=$ visible and near-IR atworption bands. $P_{1.2 .3}=$ phytol hydrogen NMR signals $\mathrm{Cl}_{2}\left(\mathrm{H}_{2}\right) . \mathrm{C}(\mathrm{HI})$ and $\mathrm{C} 3\left(\mathrm{CH}_{3}\right)$, respectively:
}

15). Synthesized by chemical reduction of (2), as described for the synthesis of (4) from (1). Spectra: absorption in ether $\lambda_{\text {max }}$ [nm] (relative intensities): $S_{A} 346$ (1.015), $S_{13} 385$ (0.64), $Q_{X} 555(0.358), Q_{Y} 729 \mathrm{~nm}(1)$; 'H-NMR in pyridine-d $d_{5}: \delta[\mathrm{ppm}]$ (proton): $8.76^{*}, 8.75^{*}$ (5-H): $8.47(10-\mathrm{H}) ; 8.13(20-\mathrm{H}) ; 5.20\left(13^{2}-\mathrm{H}\right) ; 6.26\left(13^{2}-\right.$ H): $3.30 *, 3.27 *\left(2-\mathrm{CH}_{3}\right): 1.61\left(7-\mathrm{CH}_{3}\right) ; 3.63\left(2-\mathrm{CH}_{3}\right)$; $1.55\left(18-\mathrm{CH}_{3}\right) ; 6.43\left(3^{\prime} \mathrm{H}\right) ; 7.31\left(3^{\prime}-\mathrm{OH}\right) ;(*$ split signal due to mixture of $3^{1}$ epimers).

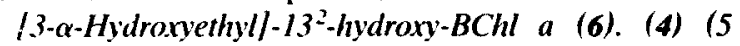
mg) was dissolved in methanol $(250 \mathrm{ml})$ and kept for 4 days at $4^{\circ} \mathrm{C}$ in the presence of air [25]. There were several products which were separated on a DEAE-cellulose column [27]. The main band contained a mixture of $3^{1} / 13^{2}$ diastereomers of (6). which were not separated. A subsequent repurification on RP-18 columns (Adsorbex. Merck) is sometimes necessary to remove by-products. Spectra: absorption in ether $\lambda_{\max }[\mathrm{nm}]$ (relative intensities): $S_{A} 346(1.14), S_{B} 386(0.84), Q_{X}$ $550(0.40), Q_{Y} 728 \mathrm{~nm}(1) ;{ }^{1} \mathrm{H}-\mathrm{NMR}$ in pyridine- $d_{\mathrm{s}}$ : $\delta[\mathrm{ppm}]$ (proton); $9.00 * 8.97 *(5-\mathrm{H}) ; 8.46(10-\mathrm{H})$; $8.12^{*}, 8.11^{*}\left(2(-\mathrm{H}) ; 5.37\left(13^{2} \mathrm{R}-\mathrm{H}\right) ; 3.26 * 3.21 *\right.$ (2- $\left.\mathrm{CH}_{3}\right) ; 3.52\left(2-\mathrm{CH}_{3}\right) ; 3.54\left(13^{2}-\mathrm{COOCH}_{3}\right) ; 6.51$ (3'$\mathrm{H})$; ${ }^{*}$ split signal due to mixture of $3^{1 / 13^{2}}$ diastereomers).

/3-Vinyl/BChl a (7). Purified (4) (1 mg) was dried in vacuum over $\mathrm{CaCl}_{2}$ for $12 \mathrm{~h}$ and then dissolved in toluene $(50 \mathrm{ml})$, dried over molecular sieve $(3 \AA)$. The mixture was refluxed under argon for 1-2 $\mathrm{h}$. The reaction was usually followed by absorption spectroscopy (red-shift of the $Q_{Y}$ band from 739 to $750 \mathrm{~nm}$ in the reaction mixture). After the reaction was completed, the solvent was removed by $35^{\circ} \mathrm{C}$ in vacuum. The final product, which was already rather pure, was purified on a DEAE-cellulose column [27]. The $13^{2}$ epimers were not separated. The high yield of the reaction was confirmed by HPLC analysis with a diode array absorption detector [14]. The silica gel system used [28], allows the separation of the $3^{1}$ and $13^{2}$ diastereomers of (4) and the $13^{2}$ epimers of (7). There are no colored by-products detectable by HPLC analysis of the final product. Spectra: absorption in ether $\lambda_{\text {max }}[\mathrm{nm}]$ (relative intensities): $S_{\mathrm{A}} 351(1.13), S_{\mathrm{B}} 389$ (0.67). $Q_{\lambda} 560(0.35), Q_{Y} 745(1) ; \epsilon_{745}\left(82.5 \pm 2.5 \cdot 10^{3}\right.$ $M^{-1} \mathrm{~cm}^{-1}$ in ether); 'H-NMR in pyridine- $d_{5}: \delta[\mathrm{ppm}]$ (proton): $8.45(5-\mathrm{H}): 8.41(10-\mathrm{H}) ; 8.14(20-\mathrm{H}) ; 8.03\left(\mathrm{H}_{\mathrm{X}}\right.$ d, $J=11.6 \mathrm{~Hz}) ; 5.94\left(\mathrm{H}_{\mathrm{A}}\right.$ d, $\left.J=11.6 \mathrm{~Hz}\right) ; 6.21\left(\mathrm{H}_{\mathrm{B}}\right.$, $\mathrm{d} . J=17.9) ; 6.44\left(13^{2} \mathrm{R}-\mathrm{H}\right) ; 6.29\left(13^{2} \mathrm{~S}-\mathrm{H}\right) ; 3.20(2-$ $\left.\mathrm{CH}_{3}\right) ; 1.68\left(7-\mathrm{CH}_{3}\right.$, d, $\left.J=7.2\right) ; 3.53\left(12-\mathrm{CH}_{3}\right) ; 1.47$ $\left(18-\mathrm{CH}_{3}\right.$, d. $\left.J=7.2 \mathrm{~Hz}\right) ; 3.75\left(13^{2}-\mathrm{COOCH}_{3}\right) ; 4.74\left(\mathrm{P}_{1}\right)$; $5.44\left(\mathrm{P}_{2}\right) ; 1.64\left(\mathrm{P}_{3}\right)$; FAB-mass: $896(M+2 \mathrm{H}, 38 \%)$; $895(M+$ H. $67 \%) ; 894\left(M^{+}, 70 \%\right) ; 616(M-$ phytol + $\mathrm{H}, 100 \%) ; 154(30 \%) ; 136 \mathrm{~m} / \mathrm{z}(24 \%)$.

/3-Vinyl/-132-demethoxycarbonyl-BChl a (8). Obtained from (7) according to Ref. 24, by refluxing in pyridine under argon for $18 \mathrm{~h}$. Spectra: absorption in 
ether $\lambda_{\max }[\mathrm{nm}]$ (relative intensities): $\mathrm{S}_{\mathrm{A}} 351$ (1.07), $\mathrm{S}_{\mathrm{B}}$ $388(0.65), Q_{X} 562(0.32), Q_{、} 747 \mathrm{~nm}(1)$ : ' $\mathrm{H}-\mathrm{NMR}$ in pyridine- $d_{5}: \delta[\mathrm{ppm}]$ (proton): $8.56(5-\mathrm{H}) ; 8.38(10-\mathrm{H})$ : $8.29(20-\mathrm{H}): 8.02\left(\mathrm{H}_{\mathrm{x}}, J_{\mathrm{AX}}=11 \mathrm{~Hz}, J_{\mathrm{B}}=18 \mathrm{~Hz}\right) ; 5.90$ $\left(\mathrm{H}_{\mathrm{A}}, \mathrm{d}, J=11.6 \mathrm{~Hz}\right) ; 6.19\left(\mathrm{H}_{\mathrm{B}} \mathrm{d}, J=17.7 \mathrm{~Hz}\right) ; 5.20$ $\left(13^{2} \mathrm{R}-\mathrm{H}, \mathrm{d}, J=19.5 \mathrm{~Hz}\right) ; 4.97\left(13^{2} \mathrm{~S}-\mathrm{H}, \mathrm{d}, J=19.4 \mathrm{~Hz}\right.$ ); $3.27\left(2-\mathrm{CH}_{3}\right) ; 1.64\left(7-\mathrm{CH}_{3}\right.$. d. $\left.J=9.6 \mathrm{~Hz}\right): 3.65(12-$ $\left.\mathrm{CH}_{3}\right) ; 1.61\left(18-\mathrm{CH}_{3} \mathrm{~d}, J=7.4 \mathrm{~Hz}\right) ; 4.74\left(\mathrm{P}_{1}\right) ; 5.45\left(\mathrm{P}_{2}\right)$; $1.66\left(P_{3}\right)$.

[3-Vinyll-132-hydroxy-BChl a (9). (7) (5 mg) was dissolved in methanol $(250 \mathrm{ml})$ and kept in the dark for 6 days at $4^{\circ} \mathrm{C}$ in the presence of air. There are several products which were separated on a DEAE-cellulose column [27]. The main fraction contains the $13^{2}$ isomeres of (9). which were not separated. A subsequent repurification on RP-18 columns (Adsorbex, Merck) was sometiries necessary. Spectra: absorption in ether $\lambda_{\max }[\mathrm{nm}]$ (relative intensities): $S_{\mathrm{A}} \mathbf{3 5 0}(1.09), S_{\mathrm{B}} 387$ (0.79), $Q_{X} 555$ (0.33), $Q_{Y} 744 \mathrm{~nm}$ (1); ' $H-N M R$ in pyridine- $d_{5}: \delta[\mathrm{ppm}]$ (proton): $8.56(5-\mathrm{H}) ; 8.55(10-\mathrm{H})$; $8.27(20-\mathrm{H}) ; 8.09\left(\mathrm{H}_{\mathrm{X}}, J_{\mathrm{AX}}=11 \mathrm{~Hz} . J_{\mathrm{B}}=18 \mathrm{~Hz}\right): 5.96$ $\left(\mathrm{H}_{\mathrm{A}}, \mathrm{d}, J=11.5 \mathrm{~Hz}\right) ; 6.24\left(\mathrm{H}_{\mathrm{B}}, \mathrm{d}, J=7.9 \mathrm{~Hz}\right) ; 3.23$ $\left(2-\mathrm{CH}_{3}\right) ; 1.71\left(7-\mathrm{CH}_{3}\right.$. d. $\left.J=7.2 \mathrm{~Hz}\right) ; 3.54\left(12-\mathrm{CH}_{3}\right)$; $1.33\left(18-\mathrm{CH}_{3}\right.$ d. $\left.J=7.1 \mathrm{~Hz}\right) ; 3.54\left(13^{2}-\mathrm{COOCH}_{3}\right): 9.45$ $\left(13^{2}-\mathrm{OH}\right) ; 4.63\left(\mathrm{P}_{1}\right) ; 5.34\left(\mathrm{P}_{2}\right) ; 1.57\left(\mathrm{P}_{3}\right)$; FAB-mass: 912 $(M+2 \mathrm{H}, 26 \%) ; 911(M+\mathrm{H}, 44 \%) ; 910\left(M^{+}, 50 \%\right)$ $632(M-$ Phytol + H. $20 \%) ; 155(100 \%), 136 \mathrm{~m} / \mathrm{z}$ $(100 \%)$.

Modified bacteriopheophytins. All metal-free products are obtained by demetalation in diethyl ether under nitrogen with $15 \% \mathrm{HCl}$ at $4^{\circ} \mathrm{C}$ from the corresponding magnesium-containing pigments $\mathbf{l}-9$. The final products were purified by preparative thin-layer chromatography on silica gel. The ahsorption spectra in diethyl ether $\lambda_{\text {nux }}$ [nm] (relative intensities) are given below. Further spectroscopical data are given in Ref. 29.

BPhe a (10): $\mathrm{S}_{\mathrm{A}} 357(1.60), \mathrm{S}_{\mathrm{B}} 384$ (0.88). $\mathrm{Q}_{\mathrm{X}} 525$ (0.40), $Q_{Y} 749 \mathrm{~nm}(1)$.

13'-Demethoxycarbonyl-BPhe a (11): $\mathrm{S}_{\mathrm{A}} 357$ (1.47), $\mathrm{S}_{\mathrm{B}} 383(0.79), \mathrm{Q}_{\mathrm{X}} 527(0.36), \mathrm{Q}_{\mathrm{Y}} 749 \mathrm{~nm}(1)$.

13'-Hydroxy-BPhe a (12): $\mathrm{S}_{\mathrm{A}} 358$ (1.54), $\mathrm{S}_{\mathrm{B}} 383$ (0.94), $\mathrm{Q}_{\mathrm{X}} 521(0.37), \mathrm{Q}_{\mathrm{Y}} 750 \mathrm{~nm}(1)$.

/3- $\alpha$-Hydroxyethyl/-BPhe a (13): $\mathrm{S}_{\mathrm{A}} 351$ (2.25), $\mathrm{S}_{\mathrm{B}}$ $378(1.34), Q_{X} 509(0.76), Q_{Y} 712 \mathrm{~nm}(1)$.

[3- $\alpha$-Hydroxyethyl/-132-demethoxycarbonyl-BPhe a (14): $S_{\mathrm{A}} 350(2.22), \mathrm{S}_{\mathrm{B}} 377(1.233), \mathrm{Q}_{\mathrm{X}} 511(0.70), \mathrm{Q}_{\mathrm{Y}}$ $713 \mathrm{~nm}(1)$.

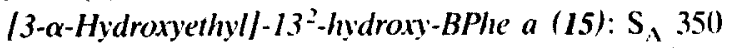
(2.20), $S_{\mathrm{B}} 376(1.46), \mathrm{Q}_{\mathrm{X}} 506(0.70), \mathrm{Q}_{\mathrm{Y}} 713 \mathrm{~nm}(1)$.

13-Vinyll-BPhe a (16): $\mathrm{S}_{\mathrm{A}} 353$ (2.31), $\mathrm{S}_{\mathrm{B}} 380(1.24)$. $Q_{\mathrm{X}} 513(0.70), Q_{\mathrm{Y}} 725 \mathrm{~nm}(1)$.

[3-Vinyl]-132-demethoxycarbonyl-BPhe a (17): $\mathrm{S}_{\mathrm{A}} 353$ (2.37), $S_{B} 380(1.31), Q_{X} 514(0.65), Q_{Y} 725 \mathrm{~nm}(1)$.

/3-Vinyll-1.32-hydroxy-BPhe a (18): $\mathrm{S}_{\mathrm{A}} 353(2.17), \mathrm{S}_{\mathrm{B}}$ $379(1.34), Q_{X} 510(0.64), Q_{Y} 726 \mathrm{~nm}(1)$.

\section{References}

I Fischer. H. and Orth. H. (19.11) Dic Chemic des Pyrrols. Vol. Il. Ind half. Akidemische Verlagsgesellschatt. Leipzig. Reprinted: Johnson Reprint Corp. New Yor: 1968.

2 Vernon. L.P. and Seely, (C.R. (eds.) (1966) The Chlorophylls. Academic Press. New York.

3 Scher. H. (ed.) (1991) Chlorophylls. CRC Press. Bocal Raton.

4 Cogdell. R.J. (1986) in Photosynthesis III - Photosynthetic Membranes and Light Harvesting Systems. (Statehelin, L.A. and Arntzen. (.J., eds.). 25.2-259. Springer. Berlin.

5 Feher. G. and Okamura. M.Y. (1978) in The Photosynthetic Bacteria. (Clayton, R.K. and Sistrom. W.R.. eds.). pp. 349--386. Plenum. Neu York.

6 Fenna, R.E., Ten Eyck. L.F. and Matthews. B.W. (1977) Biochem. Biophys. Res. Commun. 75, $751-756$.

7 Deisenholer. J.. Epp. O.. Miki. K., Huher. R. and Michel. H (1984) J. Mol. Biol. 181. 385-398: Deisenhofer. J. and Michel. H. (1989) Angew. Chem. 101. 872-892. Angew. Chem. Int. Ed. 28 $829-847$.

\& Allen. I.P.. Feher, (.. Yeates. T.O.. Komiya. H. and Rees. D.C. (1987) Proce Natl. Acad. Sci. USA 8t, 5730-5734: Alken, I.P. Feher. C. Yeates, T.O.. Komiya. II. and Rees. D.C. (1988) in The Plotosynthetic Bacterial Reaction Center - Structure and Dynamics. (Breton. J. and Verméglio. A.. eds.), NATO ASI Series. Ser. A.: Life Sciences. pp. 5-12. Plenum. New York.

9 El-Kabbani. O., Chang. ('.H.. Tiede. D.. Norris. J. and Schiffer. M. (1991) Biochemistny 30. 5361-5369: Chang. C.-11. El-Kahhani. O.. Tiede. D.. Norris. J. and Schiffer. M. (1941) Biochem. istry 30, 5352-5360.

10 Arnoux. B.. Ducruix, A., Reins-Housion. F., Lutz. M.. Norris. J. Schiffer, M. and Chang, C.H. (1989) FEBS Lett. 258. 47-.501.

11 Struck. A. and Scheer. H. (1990) FEBS Lett. 261, 385-388.

12 Struck. A.. Cmiel. E.. Katheder. 1. and Scheer. H. (1990) FEBS Lett. 268. $1801-184$

13 Struck. A.. Beese, D.. Cmiel. E.. Fischer. M.. Müller. A.. Schäfer. W. and Scheer. H. ([990) in Reaction Centers of Pholosynthetic Bacteria, (Michel-Beverle. M.E. ed.) Series in Biophysics. Vol. 6. pp. 313-326. Springer. Berlin.

If Struck. A. Miller. A. and Scheer. If. (1990) Biochim. Biophys. Actia 1060. 262-270.

15 Parkes-Loach. P.S. Sprinkle J.R. and Loach, P.A. (1988) Bio chemistry 27. 2718-2727.

16 Parkes-Loach. P.S. Michalski. T.J.. Bass. W.J., Smith. L.J. and Laoch. P.A. (1990) Biochemistry 29. $2451-2960$.

17 Ghosh. R.. Hauser. H. and Bachofen, R. (1988) Biochemistry 27. $1004-1014$.

Is Smith. J.R.L. and Calvin. M. (1966) J. Am. Chem. Soc. Rs. $+510)-4506$.

19 Falk. H., Hoornaert, C.. Menring. H.P. and Exchenmoset. $A$. (1975) Hlel. Chim. Acla 58. 2347-2357: Schecr. H. and Katz. J.J. (1078) J. Am. Chem. Soc. 1011. $561-571$.

20) Hynninen. P.H.. Wasielewsky. M.R. and Katz, J.J. (1979) Acta Chem. Scand. 33, 6.37-648: Wasielewski, M.R. Norris. J.R.. Shipman. L.L. Lin, C.P. and Svec. W.A. (1981) Proc. Natl. Acad. Sci. USA 78, 2957-2961

21 Watanabe. T.. Kobayashi. M.. Hongu. A.. Nakazato. M.. Hiyama. T. and Murata. N. (1985) FEBS Lett. 191. 252-256.

22 Mauzerall. D. and Chivis, A. (1973) J. Theor. Biol. 42. 387-395.

23 Coleman. W.J. and Youvan. D.C. (1990) Annu. Rev. Biophys. 19. 333-367.

24 Pennington. F.C. Strain. H.H.. Svec, W.A. and Katz, J.J. (1964) J. Am. Chem. Soc. Sh. $1+18-1+26$.

25 Schaber. P.M., Hunt. J.E., Fries. R. and Katz. J.J. (1984) J. Chromatogr. 316. 25-41.

26 Ditson, S.L.. Davis. R.C. and Pearlstein. R.M. (1984) Biechim. Biophys. Ac1a 766. 623-629. 


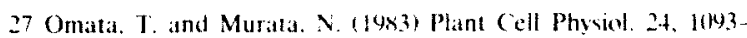
li(n).

2i: Wattunabe. T. Hongu. A. Ilondai. K.. Nahazato. M. Konno, M and Sailoh. S. 11981) Anal. (hem. 5n. 251-256.

29) Struch. A (1990) (homisch modifizicrte Bahleriochlorophylle und phaiophytine in den Bindungsstellen $B_{1}$, und $H_{A, B}$ won photosythetischen Reiationszentren alls Rhodobacter sphaeroides R26: Pigmentsynthese. Pigmentidustatixch und spek. troskopic. Dissertation. Universität Müichen.

30 Smith. K.M. and Simpion. D.J. (19K6) J. (hem. Soc. (hem. Commun. l6x:-1684.

31 Brockmann. H.J. (1478) in The Porphyrins (Dolphin. D.. Cd.). Vol. H. pp. 287-326, Academic Press. New York.

32 Holt. A.S. (1959) Plant Physiol. 34. 310-314.

33 Scheer, H. and Wolf. H. (1972) Tetrahedron Lett. 28, 5839-5856

34 Scheer. H. and Katz, J.J. (1975) in Porphyrins and Metalioporphyrins. (Smith. K.M.. ed.). pp. 399-524. Elsevier, New York.

35 Scheer. H. (1988) in CRC Handbook of Chromatography. Plant Pigments, (H.-P. Köst. ed.) Vol. 1, pn. 235-307, CRC Press, Buca R.t10n

36 Evans, T.A. and Kat/. J.J. (1975) Biochim. Bophys. Acta 396. $+1+-426$.

37 Belanger. F.C. and Reheiz. (.A. (1484) Spectrochim. Actit $411 \mathrm{~A}$ $817-827$.

38 Wolt. H. and Scheer. H. (197.3) Ann. N.Y. Acad. Sci. 2016. $549-567$.

39 Olsen. J.M. and Pedersen. J.P. (1988) in Photosynthetic Light Harvesting Systems. (Scheer, 11, and Schneider, S. eds.). pp. 365-375. W' de Gruyter. Berlin.

40 Smith. K.M. Kehres. L.A. and Fajer. J. (1983) J. Am. Chem. Soc. $105.1387-13 \times 9$.

41 Kať. J.J. Shipman, L.L., Cotton. T.M. and Janson. T.R. (1978) in The Porphyrins (Dolphin. D., ed.) Vol. V, pp. 402-458. Academic Press. New York.

42 Brune. D.C.. King. (.H. and Blankenship. R.E. (1988) in Photosynthetic Light Harvesting Systems. (Scheer, H. and Schneider. S., eds.), pp. 141-153, W. de Gruyter. Berlin.

43 Porra, R.J. (1990) Biochim. Biophys, Acta 1015, 49.3-502.

44 Seely. C.R. $(1966)$ in The Chlorophylts (Vernon, L.P. and Seely. G.R.. eds.) pp. 67. Acitdemic Press. New York.

45 Hynninen. P.H. (1991) in Chlorophylls (Scheer. H., ed.), pp. 145-210. ('RC Press, Boca Raton. th Luty. M. and Mantele, W. (1991) in Chlorophylls (Scheer, H., ed.). pp. 855-902. CRC Press. Bocat Raton.

47 Dougherty. R.C.. Stain. H.H. and Katz. J.J. (1965) J. Am. Chem. Soc. 87. 101.

48 Watanabe. T.. Nakazato, M. and Honda, K. (1986) Chem. Lett. 1986. $25.3-256$

49 Scheer. H.. Katz. J.J. and Norris. J.R. (1977) J. Am. Chem. Soc. 99. $1372-1381$.

50 Hill, R.L. and Teipel, J.W. (1971) in The Enzymes (Boyer, P. ed.). 3rd edn., Vol. V. pp. 539-571. Academic Press. Nev York

51 Bloch. K. (1971) in The Enzymes (Boyer. P.. ed.). 3rd Edn.. Vol. V. pp. 441-464., Academic Press. New York.

52 Arfin. S.M. (1969) J. Biol. Chem. 244, 2250-2251.

53 Richard, J.P. (1990) in The Chemistry of Enols. (Rapoport. Z., ed.). pp. 651-689, Wiley. New York.

54 Fedor. L.F. and Glave. W.R. (1971) J. Am. Chem. Soc. 93, $985-989$.

55 Motiu-DeGrood. R., Hunt. W.. Wilde, J. and Hupe. D.J. (1979) J. Am. Chem. Soc. 101. 2182-2190.

56 Richard, J.P. (1984) J. Am. Chem. Soc. 106, 4926-4936.

57 Amys: T.L. and Kirby, A.J. (1988) J. Am. Chem. Soc, 110. $6,5105-6.514$.

58 Hynninen. P.H. and Lotjönen. S. (1981) Tetrahedron Letl. 22. $1845-1846$.

59 Bocian. D.F., Boldt. N.J.. Chadwick. B.W. and Frank, H.A. (1987) FEBS Lell. 214, 92-96.

60) Feher. G., Isadeson. R.A.. Okamura, M.Y. and Lubitz. W. (1988) in The Photosynthetic Bacterial Reaction Center - Structure and Dynamics. (Breton. J. and Vermeglio, A.. eds.). NATO ASI Series. Ser. A: Life Sciences, pp. 231-238., Plenum. New York.

61 Nabedryk, E.. Leonhard, M., Mäntele, W. and Breton. J. (1990) Biochemistry 29, 3242-3247; Mäntele, W. Leonhard, M. Bauscher, M.. Nabedryk, E.. Breton. J. and Moss. D.A. (in press).

62 Weedon, A.C. (1990) in The Chemistry of Enols. (Rappoport, Z. ed.), pp. 591-638, Wiley \& Sons, New York.

6.3 Beckett, A. and Porter, G. (1963) Trans. Faraday Soc. 59. 20382050).

64 Beckett. A. and Porter. G. (1963) Trans. Faraday Soc. 59, 20512057. 